\title{
House dust as possible route of environmental exposure to cadmium and lead in the adult general population
}

\author{
Janneke Hogervorst $^{\mathrm{a}}$, Michelle Plusquin ${ }^{\mathrm{b}}$, Jaco Vangronsveld ${ }^{\mathrm{a}}$, Tim Nawrot ${ }^{\mathrm{b}}$, Ann Cuypers ${ }^{\mathrm{a}}$, \\ Etienne Van Hecke ${ }^{\mathrm{c}}$, Harry A. Roels ${ }^{\mathrm{d}}$, Robert Carleer ${ }^{\mathrm{a}}$, Jan A. Staessen ${ }^{\mathrm{b}, *}$ \\ ${ }^{\text {a } C e n t r u m ~ v o o r ~ M i l i e u k u n d e, ~ L i m b u r g s ~ U n i v e r s i t a i r ~ C e n t r u m, ~ D i e p e n b e e k, ~ B e l g i u m ~}$ \\ ${ }^{\mathrm{b}}$ Studiecoördinatiecentrum, Departement Hart-en Vaatziekten, Katholieke Universiteit Leuven, Belgium \\ ${ }^{\mathrm{c}}$ Onderzoeksgroep voor Sociale en Economische Geografie, Katholieke Universiteit Leuven, Belgium \\ ${ }^{\mathrm{d}}$ Unité de Toxicologie Industrielle et de Médecine du Travail, Université catholique de Louvain, Bruxelles, Belgium
}

Received 19 December 2005; received in revised form 5 May 2006; accepted 17 May 2006

Available online 13 July 2006

\begin{abstract}
Contaminated soil particles and food are established routes of exposure. We investigated the relations between biomarkers of exposure to cadmium and lead, and the metal loading rates in house dust in the adult residents of an area with a soil cadmium concentration of $\geqslant 3 \mathrm{mg} / \mathrm{kg}(n=268)$ and a reference area $(n=205)$. We determined the metal concentrations in house dust allowed to settle for $3 \mathrm{months}$ in Petri dishes placed in the participants' bedrooms. The continuously distributed vegetable index was the first principal component derived from the metal concentrations in six different vegetables. The biomarkers of exposure (blood cadmium 9.2 vs. 6.2 nmol/L; $24-\mathrm{h}$ urinary cadmium 10.5 vs. $7.0 \mathrm{nmol}$; blood lead 0.31 vs. $0.24 \mu \mathrm{mol} / \mathrm{L})$, the loading rates of cadmium and lead in house dust ( 0.29 vs. 0.12 and 7.52 vs. $3.62 \mathrm{ng} / \mathrm{cm}^{2} / 92$ days), and the vegetable indexes ( 0.31 vs. -0.44 and 0.13 vs. -0.29 standardized units) were significantly higher in the contaminated area. A two-fold increase in the metal loading rate in house dust was associated with increases $(P<0.001)$ in blood cadmium $(+2.3 \%)$, 24-h urinary cadmium $(+3.0 \%)$, and blood lead $(+2.0 \%)$, independent of the vegetable index and other covariates. The estimated effect sizes on the biomarkers of internal exposure were three times greater for house dust than vegetables. In conclusion, in the adult population, house dust is potentially an important route of exposure to heavy metals in areas with contaminated soils, and should be incorporated in the assessment of health risks.
\end{abstract}

(C) 2006 Elsevier Inc. All rights reserved.

Keywords: Cadmium; Environmental exposure; House dust; Lead; Soil; Vegetables

\section{Introduction}

Cadmium and lead are heavy metals with high toxicity, which during life accumulate in the human body (Nordberg, 2004; Järup, 2003). The 24-h urinary excretion of cadmium is a biomarker of lifetime exposure, while the concentrations of cadmium and lead in blood reflect more recent exposure (Staessen et al., 1996a, b). Commonly held points of view are that populations living in areas historically polluted by cadmium or lead are mainly exposed by consumption of crops or animal produce

\footnotetext{
${ }^{*}$ Corresponding author. Fax: + 3215414542 .

E-mail addresses: jan.staessen@med.kuleuven.be, jan.staessen@proximus.be (J.A. Staessen).
}

originating from contaminated soils (Nordberg, 2004; Järup, 2003). Young children with pica behavior can ingest considerable amounts of contaminated soil particles (Järup, 2003; Deportes et al., 1995; Sanchez-Nazario et al., 2003). Tobacco smoke and polluted air are additional sources of exposure (Nordberg, 2004; Järup, 2003). Although house dust prominently contributes to the lead body burden of children (Kimbrough et al., 1996; Aschengrau et al., 1997; Paustenbach et al., 1997; Sanchez-Nazario et al., 2003; Lanphear et al., 2002; Lanphear et al., 1998), fewer studies investigated to what extent indoor particulate matter might contribute to the environmental exposure of the general adult population. In the former participants of the Cadmium in Belgium (CadmiBel) study (Lauwerys et al., 1990; Staessen et al., 
1992a, b, 1994, 1999), we therefore explored the association between biomarkers of the exposure to cadmium and lead, and the loading rates of these metals in house dust, while adjusting for other routes of exposure, such as the consumption of vegetables and other significant covariates.

\section{Materials and methods}

\subsection{Study areas and participants}

The Flemish CadmiBel participants were recruited from 1985 to 1989 (Lauwerys et al., 1990; Staessen et al., 1992a, b, 1994, 1999). They lived in the northeast of Belgium (Noorderkempen), close to the border with The Netherlands. The environmentally contaminated area of $259 \mathrm{~km}^{2}$ has an estimated population of 80000 inhabitants, borders on three zinc smelters, and consists of parts of the municipalities Balen, Lommel, and Overpelt (Fig. 1). This area remains historically polluted by heavy metals, in spite of the dismantlement of the smelter in Lommel in 1974, the transition from pyrolytic to electrolytic zinc refining in Overpelt in 1974, and the complete stop of the production of cadmium in Overpelt and Balen in 1992 and 2002, respectively (Staessen et al., 1995). The reference area with 9390 inhabitants is located more then $10 \mathrm{~km}$ upwind of the smelters and includes the villages Hechtel and Eksel (Fig. 1).

The CadmiBel study (1985-1989) included 1107 participants (78.0\%) of 1419 randomly selected participants with a minimum age of 20 years (Lauwerys et al., 1990; Staessen et al., 1992a, b). After exclusion of people who had died $(n=83)$, those who were severely ill $(n=3)$, and those who had moved $(n=7), 1014$ participants remained in follow-up (Staessen et al., 1994, 1999). The present analysis includes 473 subjects $(46.6 \%)$ randomly selected from the CadmiBel cohort for collection of dust in their homes.

\subsection{Biomarkers of internal exposure}

From 1991 until 1994, the participants collected a 24-h urine sample and provided a venous blood sample within 2 weeks of the urine collection (Lauwerys et al., 1990; Staessen et al., 1992a, b, 1994, 1999). They also completed a standardized questionnaire inquiring into their current and past occupations, social class, smoking habits, intake of alcohol, and consumption of home-grown vegetables and well water. Socio-economic status was coded according to a British classification (Office of Population Censuses and Surveys, 1980) and the code numbers were condensed into a scale with scores ranging from 1 (low) to 3 (high). With the help of the company doctor of the zinc refining plants, we checked for all participants, who had reported exposure to cadmium at work, their employment history, and their role in the production process.

Blood lead and cadmium in blood and urine were measured with an electrothermal atomic absorption spectrometer equipped with a stabilizedtemperature platform furnace and Zeeman background correction (Lauwerys et al., 1990; Claeys et al., 1992). In the external quality control program, the accuracy of the cadmium measurements did not show any significant time trend (Claeys et al., 1992).

\subsection{Measurement of external exposure}

From 1985 to 1989 , soil samples were taken from 307 gardens owned by the CadmiBel participants (Staessen et al., 1994). From the top layer of the soil in each garden 10 specimens were obtained at depths ranging from 0 to $25 \mathrm{~cm}$ (Buchet et al., 1990; Staessen et al., 1994). The samples were
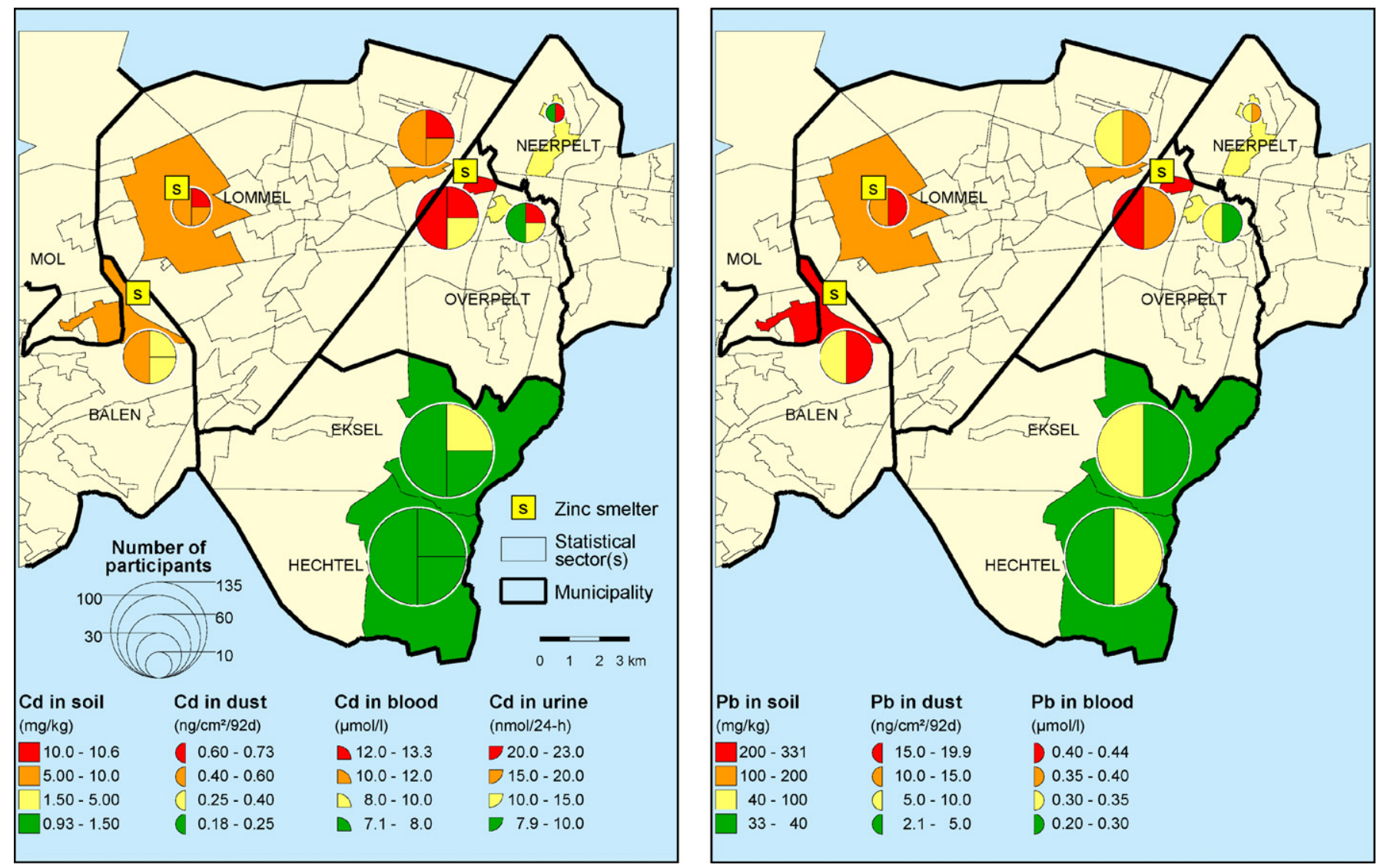

Fig. 1. Geographic distribution of study participants, smelters, and indexes of internal and external exposure. 
dried for $24 \mathrm{~h}$ at $60^{\circ} \mathrm{C}$, passed through a $2 \mathrm{~mm}$ sieve, blended, and digested in aqua regia.

House dust was allowed to settle for a 3-month period in polystyrene Petri dishes, which the field workers set out in the bedrooms of 473 participants (295 houses). The dishes were placed from 1996 through 2004 on a cupboard or shelf approximately $2 \mathrm{~m}$ high, away from doors and windows. This technique was first described by Que Hee et al. (1985). After collection, they were rinsed with $3.5 \mathrm{~mL} 70 \%$ suprapure nitric acid (J.T. Baker, Deventer, The Netherlands). The solution was then evaporated at $80^{\circ} \mathrm{C}$. The residue was dissolved in $1 \mathrm{~mL} 70 \%$ suprapure nitric acid and diluted with ultrapure water up to $5 \mathrm{~mL}$. Before use, all laboratory utensils were rinsed three times with $10 \%$ hydrochloric acid, three times with distilled water, and three times with ultrapure water. We expressed exposure to cadmium and lead via house dust as the metal loading rate by dividing the mass of metal deposited per $\mathrm{cm}^{2}$ by the collection period standardized to 92 days.

From 1996 through 2004, participants, who owned a kitchen garden, provided samples of beans, carrots, celery, leek, lettuce, and/or potatoes, as available. They also completed a food frequency questionnaire, which provided standardized information on the consumption of vegetables from kitchen gardens and grocery stores, and external media. Cadmium and lead were measured in duplicate by graphite furnace atomic absorption spectrometry with Zeeman background correction.

\subsection{Geographic analyses}

The participants' houses and the zinc smelters were located by use of the global positioning system, GPS Pathfinder Pro XL (Trimble Navigation Europe, Hampshire, UK). Degrees longitude and latitude (ellipsoid WGS84) were converted into kilometers with the Lambert projection system of Belgian maps. We used SAS/GRAPH mapping software (SAS Institute Inc, Cary, NC) and the database of Teleatlas (Ghent, Belgium). To protect privacy, we calculated spatial summary statistics across statistical units, as defined by the National Institute of Statistics (Brussels, Belgium).

\subsection{Statistical methods}

For database management and statistical analysis, we used the SAS software package, version 8.2 (SAS Institute Inc., Cary, NC). We logtransformed non-normally distributed data. To represent the central tendency and spread of non-Gaussian distributions, we used the geometric mean and the 5th and 95th percentile interval. Means and proportions were compared using the standard normal $z$-test and Fisher's exact test, respectively. Our statistical methods also included single regression and stepwise multiple regression, terminating when all $P$ values for variables to enter and stay in the models were 0.15 or less. The covariates considered as possible determinants of the biomarkers of exposure were sex, age (linear and squared terms), body mass index, the serum ferritin concentration, the activity of $\gamma$-glutamyltransferase measured in serum by an automated enzymatic technique as a marker of alcohol intake, design variables coding for current smoking $(0,1)$, occupational exposure $(0,1)$, use of drinking water from private wells $(0,1)$, and social class $(1,2,3)$, and the cadmium concentration in the soil.

To investigate the exposure to cadmium and lead via consumption of the six vegetables under study, we multiplied the amounts eaten by the metal concentration in these plants. The dietary intake of metals was computed from reported food frequencies using mean consumption portions (Breedveld et al., 1996). To impute the concentrations of these metals in vegetables not grown in the participants' kitchen gardens, but procured via grocery stores, we first regressed in the present dataset the metal concentrations in vegetables on the levels in the soil (Römkens et al., 2005). From these equations, we then estimated the concentrations of cadmium and lead in each of the six vegetables under study at background soil concentrations of 0.8 and $40 \mathrm{mg}$ per kilogram dry matter, respectively (Denneman and Robberse, 1990; Römkens et al., 2005).
We applied principal component analysis as implemented in the PROC PRINCOMP procedure of the SAS package, to summarize the daily intake of cadmium and lead from the six vegetables into a single normally distributed exposure measurement (with mean 0 and standard deviation 1), which we termed the vegetable index. Factor loading (the product-moment correlation) was used to describe the linear association between the vegetable index and the concentrations of cadmium or lead in the six vegetables.

\section{Results}

\subsection{Characteristics of the participants}

The 473 subjects were 49.9 years old (range 24.7-82.7 years) and included $241(51.0 \%)$ women. Their demographic characteristics by level of environmental exposure (low vs. high-exposure area) appear in Table 1. Occupational exposure and lower social class were more prevalent in the polluted area, whereas the opposite was true for consuming water from private wells. This was also the case for current smoking $(73(35.6 \%)$ vs. $68(25.4 \%))$, but in smokers the median daily tobacco consumption was similar in the 2 areas (16 cigarettes, interquartile range 10-20).

\subsection{Indexes of internal and external exposure}

The concentrations of cadmium and lead in blood and the 24-h urinary cadmium excretion were significantly higher in the polluted area (Table 1). As expected, most indexes of external exposure to cadmium and lead were higher in the polluted than in the reference area (Table 2). The cadmium and lead loading rates in house dust were highly correlated $(r=0.75, P<0.0001)$. The cadmium loading rate was significantly $(P<0.0001)$ correlated with the cadmium concentration in the soil $(r=0.54)$ and the distance from the zinc smelters $(r=-0.42)$. For lead, these correlation coefficients $(P<0.0001)$ were 0.39 and -0.41 , respectively.

The concentrations of cadmium and lead in the six vegetables under study (Table 2) were higher in the polluted compared to the low-exposure area with the exception of the lead concentrations in carrots $(P=0.99)$, lettuce $(P=0.08)$, and potatoes $(P=0.07)$. The first principal component had factor loadings on the metal concentrations, ranging from 0.49 (lettuce) to 0.26 (beans) for cadmium and from 0.53 (leek) to 0.24 (celery) for lead. The eigenvalues for the first principal component were 2.61 for cadmium and 1.92 for lead, and dropped to 1.37 and 1.11 for the second principal component. We therefore defined the first principal components as the vegetable indexes. These continuous parameters, summarizing the integrated exposure to cadmium or lead via vegetables locally grown or bought in grocery stores were significantly higher in the high- than low-exposure area (Table 2).

\subsection{Relation between internal and external exposure}

Unadjusted analyses based on geographic localization (Fig. 1) or thirds of the distributions of the metal loading 
Table 1

Characteristics of the participants

\begin{tabular}{|c|c|c|c|}
\hline Number of subjects & $\begin{array}{l}\text { Low exposure area } \\
268\end{array}$ & $\begin{array}{l}\text { High exposure area } \\
205\end{array}$ & $P$ \\
\hline \multicolumn{4}{|l|}{ Demographics } \\
\hline Age (years) & $50.6 \pm 13.6$ & $47.1 \pm 13.3$ & 0.19 \\
\hline Body mass index $\left(\mathrm{kg} / \mathrm{m}^{2}\right)$ & $26.2 \pm 4.5$ & $26.4 \pm 4.8$ & 0.57 \\
\hline \multicolumn{4}{|l|}{ Lifestyle } \\
\hline \multicolumn{4}{|l|}{ Socio-economic class } \\
\hline Low (no.) & $192(71.6)$ & $174(84.9)$ & \\
\hline Medium (no.) & $68(25.4)$ & $31(15.1)$ & \\
\hline High (no.) & $8(3.0)$ & $0(0)$ & $<0.0001$ \\
\hline Drinking alcohol (no.) & $52(19.4)$ & $38(18.4)$ & 0.81 \\
\hline Distance to nearest smelter $(\mathrm{km})$ & $10.8(8.0-13.6)$ & $1.0(0.4-2.1)$ & $<0.0001$ \\
\hline \multicolumn{4}{|l|}{ Biomarkers of internal exposure } \\
\hline Serum ferritin $(\mathrm{pmol} / \mathrm{L})$ & $96(20-586)$ & $121(20-577)$ & 0.012 \\
\hline Blood cadmium (nmol/L) & $6.2(1.8-21.4)$ & $9.2(2.7-27.6)$ & $<0.0001$ \\
\hline Urinary cadmium (nmol/24-h) & $7.0(2.2-19.6)$ & $10.5(2.8-32.7)$ & $<0.0001$ \\
\hline Blood lead $(\mu \mathrm{mol} / \mathrm{L})$ & $0.24(0.09-0.64)$ & $0.31(0.13-1.02)$ & $<0.0001$ \\
\hline
\end{tabular}

Statistics are arithmetic mean $\pm \mathrm{SD}$, geometric mean (5th-95th percentile interval), or number of subjects (\%). $P$ values are for the comparison between the two areas.

Table 2

Metal concentrations in external media from areas with low and high environmental exposure

\begin{tabular}{|c|c|c|c|c|c|c|c|c|}
\hline & \multicolumn{4}{|c|}{ Cadmium } & \multicolumn{4}{|c|}{ Lead } \\
\hline & \multicolumn{2}{|c|}{ Low exposure area } & \multicolumn{2}{|c|}{ High exposure area } & \multicolumn{2}{|c|}{ Low exposure area } & \multicolumn{2}{|c|}{ High exposure area } \\
\hline & $n$ & Statistic & $n$ & Statistic & $n$ & Statistic & $n$ & Statistic \\
\hline Soil $\left(\mathrm{mg} / \mathrm{kg}^{\mathrm{a}}\right)$ & 48 & $0.9(0.4-1.6)$ & 85 & $5.3(1.4-18.9)^{* * *}$ & 48 & $26.7(9.5-72.9)$ & 85 & $175(133-231)^{* * *}$ \\
\hline $\begin{array}{l}\text { Loading rate in } \\
\text { house dust (ng/ } \\
\mathrm{cm}^{2} / 92 \text { days) }\end{array}$ & 169 & $0.12(0.03-0.60)$ & 126 & $0.29(0.06-1.50)^{* * *}$ & 169 & $3.62(1.0-18.30)$ & 126 & $7.52(1.94-28.8)^{* * *}$ \\
\hline \multicolumn{9}{|l|}{ Vegetables } \\
\hline Celery (mg/kg) & 53 & $0.21(0.06-0.55)$ & 21 & $0.61(0.16-16.0)^{* * *}$ & 53 & $0.18(0.06-0.43)$ & 21 & $0.29(0.14-0.87)^{* * *}$ \\
\hline Lettuce $(\mathrm{mg} / \mathrm{kg})$ & 54 & $0.11(0.03-0.28)$ & 22 & $0.35(0.07-1.29)^{* * *}$ & 54 & $0.13(0.05-0.57)$ & 22 & $0.19(0.09-0.61)$ \\
\hline Leek (mg/kg) & 51 & $0.06(0.02-0.23)$ & 24 & $0.16(0.04-0.62)^{* * *}$ & 51 & $0.06(0.01-0.21)$ & 24 & $0.10(0.04-0.22)^{* * *}$ \\
\hline Carrots $(\mathrm{mg} / \mathrm{kg})$ & 49 & $0.06(0.03-0.14)$ & 21 & $0.14(0.04-0.40)^{* * *}$ & 49 & $0.10(0.04-0.22)$ & 21 & $0.10(0.03-0.49)$ \\
\hline Potatoes $(\mathrm{mg} / \mathrm{kg})$ & 35 & $0.02(0.01-0.06)$ & 16 & $0.06(0.02-0.18)^{* * *}$ & 35 & $0.01(0.01-0.08)$ & 16 & $0.04(0.02-0.52)$ \\
\hline Beans (mg/kg) & 44 & $0.01(0.01-0.02)$ & 24 & $0.01(0.01-0.07)^{* *}$ & 44 & $0.03(0.01-0.10)$ & 24 & $0.05(0.01-0.18)^{* * *}$ \\
\hline $\begin{array}{l}\text { Vegetable index } \\
\text { (standardized } \\
\text { units) } \\
\text { b }\end{array}$ & 272 & $-0.44 \pm 0.57$ & 202 & $0.31 \pm 1.98^{* * *}$ & 272 & $-0.29 \pm 0.57$ & 202 & $0.13 \pm 1.54 * *$ \\
\hline
\end{tabular}

Statistics are geometric mean (5th-95th percentile interval) or arithmetic mean \pm SD. $n$ indicates the number of samples. All comparisons between the areas with low- and high-exposure were statistically significant $(* * P<0.01 ; * * * P \leqslant 0.001)$, except for the lead concentrations in carrots $(P=0.99)$, lettuce $(P=0.08)$, and potatoes $(P=0.07)$.

${ }^{\mathrm{a}}$ Concentrations in soil and vegetables are given in milligram per kilogram dry weight.

${ }^{\mathrm{b}}$ The vegetable index was obtained by principal component analysis from the metal concentrations in the six vegetables (see Methods for further details). 
rates in house dust (Fig. 2) revealed positive associations with the biomarkers of internal exposure. In stepwise multiple-regression models (Table 3), a two-fold increase in the loading rate of cadmium in house dust was associated with a $2.3 \%$ and $3.0 \%$ rise in blood and 24-h urinary cadmium, respectively, independent of the vegetable index and other covariates. A two-fold increase in the loading rate of lead in house dust was significantly and independently associated with a $2.0 \%$ increase in the blood lead concentration (Table 3). A doubling of the vegetable index was also associated with independent increases in blood cadmium, 24-h urinary cadmium, and blood lead by $0.7 \%$, $0.6 \%$, and $0.7 \%$, respectively. The estimated effects on the biomarkers of internal exposure were therefore three times greater for house dust than vegetables. Body mass index, alcohol intake, the activity of $\gamma$-glutamyltransferase in serum, and the use of drinking water from private wells did not enter any of the regression models. Fig. 3 shows the fully adjusted and independent contributions of the metal loading rates in house dust and the vegetable indexes to the variability in the biomarkers of internal exposure.

Sensitivity analyses with exclusion of participants, who were occupationally exposed or consumed water from private wells, were confirmatory without change in the magnitude and significance of the partial regression coefficients for the metal loading rates. If we excluded subjects, who exclusively consumed vegetables bought at grocery stores, the partial regression coefficients for the cadmium loading rates were $0.059 \pm 0.031(P=0.06)$ for blood cadmium and $0.080 \pm 0.027(P<0.0027)$ for urinary cadmium. With the same subjects excluded, the partial regression coefficient for blood lead in relation to the lead loading rate in house dust weakened to $0.042 \pm 0.026$ $(P=0.10)$.

\section{Discussion}

The main finding of the present study was that the loading rates of cadmium and lead in house dust were associated with the biomarkers of internal exposure and that this association was independent of the vegetable index. The estimated effects on the biomarkers of internal exposure were three times greater for house dust than vegetables. The ratios of the mean loading rates in house dust of the polluted area vs. the reference area were 2.4 for cadmium and 2.1 for lead. According to our regression
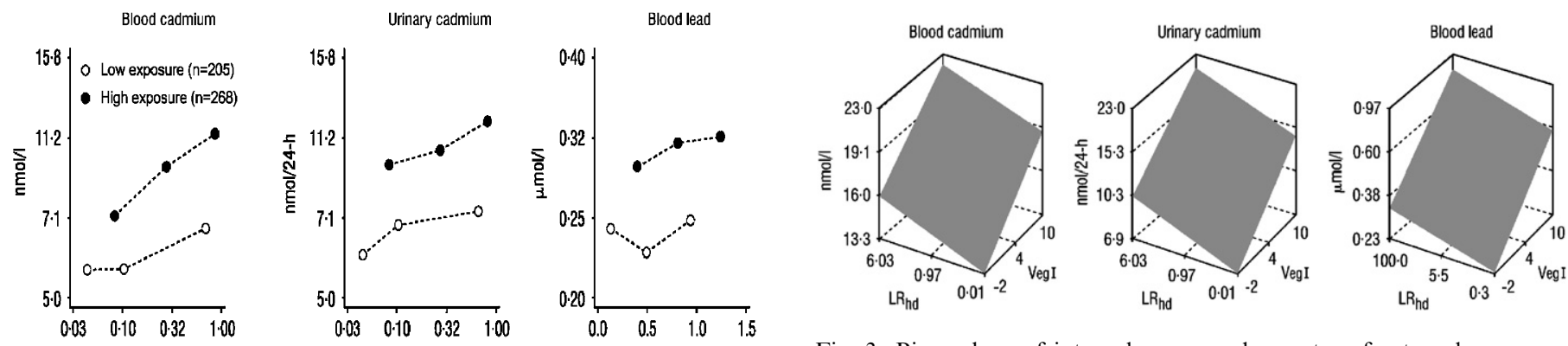

Fig. 2. Biomarkers of internal exposure by thirds of the metal loading rates in house dust $\left(\mathrm{ng} / \mathrm{cm}^{2} / 92\right.$ days).

Fig. 3. Biomarkers of internal exposure by routes of external exposure. $\mathrm{LR}_{\mathrm{hd}}$ and VegI indicate the metal loading rate in house dust $\left(\mathrm{ng} / \mathrm{cm}^{2} / 92\right.$ days) and the vegetable index (standardized units), respectively.

Table 3

Correlates of the biomarkers of internal exposure in stepwise multiple regression

\begin{tabular}{|c|c|c|c|}
\hline Regression parameters & Blood cadmium $(\log \mathrm{nmol} / \mathrm{L})$ & Urinary cadmium (log nmol/24-h) & Blood lead $(\log \mu \mathrm{mol} / \mathrm{L})$ \\
\hline Square of multiple regression coefficient & 0.41 & 0.42 & 0.38 \\
\hline \multicolumn{4}{|l|}{ Partial regression coefficients (SE) } \\
\hline Sex (male 1 , female 2 ) & ns & $-0.058(0.023)^{* *}$ & $-0.203(0.019)^{* * *}$ \\
\hline Age (years) & $0.0088(0.0010)^{* * *}$ & $0.0523(0.0056)^{* * *}$ & $0.0190(0.0049)^{* * * *}$ \\
\hline Occupational exposure $(0,1)$ & $0.208(0.068)^{* * *}$ & $0.257(0.061)^{* * *}$ & $0.219(0.052)^{* * *}$ \\
\hline Low, middle, high social class $(1,2,3)$ & ns & $-0.060(0.025)^{* *}$ & $-0.045(0.022)^{* *}$ \\
\hline Serum ferritin $(\log \mathrm{pmol} / \mathrm{L})$ & $-0.067(0.029)^{*}$ & ns & ns \\
\hline Vegetable index (standardized units) & $0.023(0.008)^{* * *}$ & $0.019(0.008)^{* * *}$ & $0.022(0.008)^{* * *}$ \\
\hline Metal loading rate in house dust (log $\mathrm{g} / \mathrm{cm}^{2} / 92$ days) & $0.076(0.027)^{* * *}$ & $0.101(0.023)^{* *}$ & $0.067(0.023)^{* * *}$ \\
\hline
\end{tabular}

Significance of the partial regression coefficients: $n s=$ not significant; $* P<0.05 ; * * P<0.01 ; * * * P<0.001$. Body mass index, alcohol intake $(0,1)$, the activity of $\gamma$-glutamyltransferase in serum, and the use of drinking water from private wells $(0,1)$ did not enter any of the regression models. 
models, while accounting for the covariance between the predictor variables, exposure via house dust and consumption of vegetables would on average result in a $4.3 \%$ higher 24-h urinary cadmium excretion and a $2.0 \%$ higher blood lead concentration in the polluted area. However, many people residing close to the zinc smelters were exposed to much higher loading rates of cadmium and lead than reflected by the geometric means of these highly skewed distributions. For instance, the average cadmium loading rate in houses within $1 \mathrm{~km}$ of the zinc smelters was five-fold higher than the geometric mean of the reference area. This would result in a $12.4 \%$ higher urinary cadmium excretion. Previous studies demonstrated clinically significant effects of such exposure levels in terms of renal dysfunction (Staessen et al., 1992a, b, 1994), osteoporosis (Staessen et al., 1999), and the incidence of bone fractures (Staessen et al., 1999). Moreover, the International Agency for Research on Cancer (IARC) classified cadmium as a known human carcinogen (group 1). Observational studies showed an association between lung cancer and the inhalation of cadmium at work (Verougstraete et al., 2003; Waalkes, 2003). With follow-up of the CadmiBel cohort now running from 1985 until 2004, the incidence of lung cancer was significantly greater in the polluted than in the reference area with rates of 1.80 and 0.38 cases per 1000 person-years, respectively (Nawrot et al., 2006). These observations underscore the potential role of inhaled fine particulate as a major source of the cadmium body burden and suggest that the epithelia of the lower airways not only act as an important transmission route, but also as a firstline target organ falling victim to the mutagenic actions of cadmium (Verougstraete et al., 2003; Waalkes, 2003).

In case of contamination of the soil by cadmium or lead, consumption of home-grown crops and ingestion of soil particles are well established routes for environmental exposure (Hough et al., 2003). However, a growing body of evidence (Paustenbach et al., 1997) suggests that exposure to soil brought indoors, present as house dust, might also stand for a critical route of exposure. In developed countries, people spend $90 \%$ or more of their time indoors and for little of the time spent outdoors they come into direct contact with soil (Paustenbach et al., 1997). House dust is largely composed of finer particles than soil. Particles with a diameter exceeding $150 \mu \mathrm{m}$ represented $80 \%$ of external soil, but only $50 \%$ of house dust (Roberts et al., 1991; Paustenbach et al., 1997). In addition to being more mobile, fine particles adhere to skin more effectively, thus increasing the potential of exposure (Kissel et al., 1996). Of the dust on the hands of children, $98 \%$ is less than $10 \mu \mathrm{m}$ in diameter (Duggan and Inskip, 1985). Fine particles also increase the bioavailability of the contaminants they carry. Furthermore, the indoor environment is characterized by limited sunlight, relatively constant temperature and low humidity, no wind or rain dispersion, a relatively low microbial population, and lack of reactive surfaces. As a consequence, the degrading or aging processes that are effective at removal or reduction of contaminants outside do not operate or operate at reduced efficiency indoors compared to outdoors (Paustenbach et al., 1997). Contaminants indoors are protected from degradation or removal by numerous traps within the home, particularly carpets, drapes, and upholstery. In general, the concentrations of contaminants are greater in house dust compared to exterior soil. For instance, in a review of 15 studies, the median of the concentration ratios of lead in house dust vs. external soil was 2.3 with a range from 0.3 to 9.2 (Paustenbach et al., 1997). Taken together, in line with the present observations, previous studies suggest that house dust is a potentially important source of exposure, not only in children (Sanchez-Nazario et al., 2003), but in adults as well (Paustenbach et al., 1997).

A German study assessed exposure to cadmium and lead by measurement of the metal concentrations in house dust (Meyer et al., 1999). It included 381 women, 52-59 years old, who lived either in three regions with mines, nonferrous smelters, and chemical industry, or in an agricultural area. Overall, the geometric mean loading rate in house dust was $0.012 \mu \mathrm{g} / \mathrm{m}^{2} /$ day $\left(0.11 \mathrm{ng} / \mathrm{cm}^{2} / 92\right.$ days $)$ for cadmium and $0.56 \mu \mathrm{g} / \mathrm{m}^{2} /$ day $\left(5.15 \mathrm{ng} / \mathrm{cm}^{2} / 92\right.$ days $)$ for lead. These values were therefore substantially lower than in the present study. The loading rates increased with higher industrial activity, more ventilation of the houses, coal vs. central heating, crowding, and the age of the buildings. The German Environmental Survey 1990/1992 (Seifert et al., 2000) was a large-scale representative population study, which involved 736 children (6-14 years) and 4021 adults (25-69 years). Among adults (Hoffmann et al., 2000), the geometric mean concentrations of cadmium and lead in the blood were $0.36 \mu \mathrm{g} / \mathrm{L}$ $(3.20 \mathrm{nmol} / \mathrm{L})$ and $45.3 \mu \mathrm{g} / \mathrm{L}(0.22 \mu \mathrm{mol} / \mathrm{L})$. Children had lower levels, but nearly $1 \%$ had a blood lead concentration exceeding $100 \mu \mathrm{g} / \mathrm{L}$. The deposition of cadmium and lead in the homes averaged $11.7 \mathrm{ng} / \mathrm{m}^{2} /$ day $\left(0.11 \mathrm{ng} / \mathrm{cm}^{2} / 92\right.$ days $)$ and $0.29 \mu \mathrm{g} / \mathrm{m}^{2} /$ day $\left(2.67 \mathrm{ng} / \mathrm{cm}^{2} / 92\right.$ days), respectively. Smoking cigarettes and age were the main determinant of blood cadmium, while environmental and occupational exposure played only a minor role (Hoffmann et al., 2000).

The present study must be interpreted within the context of its limitations. First, we demonstrated an independent association between the biomarkers of internal exposure and the loading rates of cadmium and lead in house dust. We did not prove that house dust effectively represents a route of exposure, because we cannot exclude with certainty that the metal loading rates in house dust only reflect the overall environmental pollution. Second, we could not determine the weight of the very small samples of house dust and hence the metal concentrations in house dust. However, the loading rate integrates metal concentration and the amount of dust, and is therefore the most relevant measurement to evaluate exposure to heavy metals via house dust (United States Environmental Protection Agency, 1995). Another limitation of our study is that, we measured the biomarkers of internal exposure on average 5-7 years before the collection of house dust and 
vegetables. Because of this time lag, the correlations of the biomarkers of internal exposure with the concentrations of the toxic metals in house dust and vegetables might have been stronger than those currently reported. Indeed, we previously demonstrated that over a 5-year period, with a massive decrease in the emissions of the non-ferrous smelters in the polluted area (Staessen et al., 1995) and the gradual introduction of unleaded fuel in Belgium, the concentrations of cadmium and lead in blood dropped by approximately 30\% (Staessen et al., 1996a, b, 2000), whereas the urinary excretion of cadmium declined by only 15\% (Staessen et al., 2000). That the associations of the blood concentrations of cadmium and lead with the external markers of exposure were similar as those for 24-h urinary cadmium underscores the consistency of our findings and might reflect the persistent nature of these pollutants in house dust (Paustenbach et al., 1997).

Cadmium and lead are common environmental pollutants in industrialized and developing nations. If confirmed, our findings may have important implications for the assessment and management of the associated health risks. Experts increasingly recognize that house dust might substantially contribute to the body burden, particularly in children. However, many algorithms to estimate health risks, such as the Dutch CSOIL model (Römkens et al., 2005), do not specifically account for exposure via house dust. In areas with contaminated soils, the cadmium content of vegetables can be reduced by stabilizing cadmium in the soil by organic matter or other additives, or by increasing the $\mathrm{pH}$ (Vangronsveld et al., 1994; Staessen et al., 1995). Removal of contaminated soil is a more invasive and expensive approach. Such measures are currently being implemented (Vangronsveld et al., 1994; Staessen et al., 1995) or planned for in the Noorderkempen area. However, as suggested by the present and other studies (Kimbrough et al., 1996; United States Environmental Protection Agency, 1996; Aschengrau et al., 1997; Paustenbach et al., 1997), preventive measures that do not decrease exposure to house dust might not substantially reduce the biomarkers of internal exposure. In an intervention study (Kimbrough et al., 1994), which aimed to reduce exposure of children living in a smelter area, simple techniques, such as hand washing and dust control were implemented. An average drop of the blood levels by $50 \%$ occurred immediately and persisted for 1 year. Because the reduction was achieved in the presence of elevated soil concentrations and lead paint in many of the homes, the researchers concluded that controlling house dust is critical in reducing the body burden of heavy metals (Kimbrough et al., 1994).

In conclusion, in the adult population, house dust is potentially an important and long-lived source of exposure to heavy metals in areas with contaminated soils, and should be incorporated in the assessment of health risks.

\section{Acknowledgments}

The authors acknowledge the expert assistance of $\mathrm{J}$. Boon, S. Covens, L. Gijsbers, M.J. Jehoul, H. Vanden- hoeck, and S. Van Hulle (University of Leuven, Belgium), and G. Cuyvers, C. Put, K. Smeets, and A. Wijgaerts (Centre for Environmental Sciences, Limburg University Centre, Diepenbeek, Belgium).

Conflict of interest and source of funding. None of the authors has a conflict of interest to declare. The study was funded from the research budgets of the Centre for Environmental Sciences (Limburg University Centre, Diepenbeek, Belgium) and the Studies Coordinating Centre, Laboratory of Hypertension, Department of Cardiovascular Diseases (University of Leuven, Belgium).

\section{References}

Aschengrau, A., Beiser, A., Bellinger, D., Copenhafer, D., Weitzman, M., 1997. Residential lead-based-paint hazard remediation and soil abatement: their impact among children with mildly elevated blood lead levels. Am. J. Public Health 87, 1698-1702.

Breedveld, B.C., Hammink, J., van Oosten, H.M., 1996. Nederlandse Voedingsmiddelentabel. Voorlichtingsbureau voor de Voeding, Den Haag, The Netherlands.

Buchet, J.P., Lauwerys, R., Roels, H., Bernard, A., Bruaux, P., Claeys, F., Ducoffre, G., De Plaen, P., Staessen, J., Amery, A., Lijnen, P., Thijs, L., Rondia, D., Sartor, F., Saint-Remy, A., Nick, L., 1990. Renal effects of cadmium body burden of the general population. Lancet 336, 699-702.

Claeys, F., Ducoffre, G., Sartor, F., Roels, H., 1992. Analytical quality control of cadmium and lead in blood and cadmium in urine : results of its implementation during a five-year epidemiological study. In: Nordberg, G.F., Herber, R.F.M., Alessio, L. (Eds.), Cadmium in the Human Environment: Toxicity and Carcinogenicity, vol. 118. International Agency for Research on Cancer, IARC Scientific Publications, Lyon, pp. 83-92.

Denneman, P.R.J., Robberse, J.G., 1990. In: Arendt, F., Hinsenfeld, H., van den Brink, W.J. (Eds.), Ecotoxicological Risk Assessment as a Base for Development of Soil Quality Criteria. Kluwer, Dordrecht, The Netherlands, pp. 157-164.

Deportes, I., Benoit-Guyod, J.L., Zmirou, D., 1995. Hazard to man and the environment posed by the use of urban waste compost: a review. Sci. Total Environ. 172, 197-222.

Duggan, M.J., Inskip, M.J., 1985. Childhood lead exposure to lead in surface dust and soils: a community health problem. Public Health Rev. 13, 1-54.

Hoffmann, K., Becker, K., Friedrich, C., Helm, D., Krause, C., Seifert, B., 2000. The German Environmental Survey 1990/1992 (GerES II) : cadmium in blood, urine and hair of adults and children. J. Expo. Anal. Environ. Epidemiol. 10, 552-565.

Hough, R.L., Breward, N., Young, S.D., Crout, N.M., Tye, A.M., Moir, A.M., Thornton, I., 2003. Assessing potential risk of heavy metal exposure from consumption of home-produced vegetables by urban populations. Environ. Health Perspect. 112, 215-221.

Järup, L., 2003. Hazards of heavy metal contaminants. Br. Med. Bull. 68, $167-182$.

Kimbrough, R., LeVois, M., Webb, D.R., 1994. Management of children with slightly elevated blood lead levels. Pediatrics 93, 188-191.

Kimbrough, R., LeVois, M., Webb, D., 1996. Survey of lead exposure around a lead smelter. Pediatrics 95, 540-554.

Kissel, J.C., Richter, K.Y., Fenske, R.A., 1996. Field measurements of dermal soil loading attributable to various activities: implications for exposure assessment. Risk Anal. 16, 115-125.

Lanphear, B.P., Matte, T.D., Rogers, J., Clickner, R.P., Dietz, B., Bornschein, R.L., Succop, P., Mahaffey, K.R., Dixon, S., Galke, W., Rabinowitz, M., Farfel, M., Rohde, C., Schwartz, J., Ashley, P., 
Jacobs, D.E., 1998. The contribution of lead-contaminated house dust and residential soil to children's blood lead levels. A pooled analysis of 12 epidemiologic studies. Environ. Res. 79, 51-68.

Lanphear, B.P., Hornung, R., Ho, M., Howard, C.R., Eberly, S., Knauf, K., 2002. Environmental lead exposure during early childhood. J. Pediatr. 140, 40-47.

Lauwerys, R., Amery, A., Bernard, A., Bruaux, P., Buchet, J.P., Claeys, F., De Plaen, P., Ducoffre, G., Fagard, R., Lijnen, P., Nick, L., Roels, H., Rondia, D., Saint-Remy, A., Sartor, F., Staessen, J., 1990. Health effects of environmental exposure to cadmium : objectives, design and organization of the Cadmibel study : a cross-sectional morbidity study carried out in Belgium from 1985 to 1989. Environ. Health Perspect. 87, 283-289.

Meyer, I., Heinrich, J., Lippold, U., 1999. Factors affecting lead and cadmium levels in house dust in industrial areas of eastern Germany. Sci. Total Environ. 234, 25-36.

Nawrot, T., Plusquin, M., Hogervorst, J., Roels, H.A., Celis, H., Thijs, L., Vangronsveld, J., Van, H.E., Staessen, J.A., 2006. Environmental exposure to cadmium and risk of cancer: a prospective populationbased study. Lancet Oncol. 7, 119-126.

Nordberg, G.F., 2004. Environmental exposure and preventive measures in Sweden and EU. Biometals 17, 589-592.

Office of Population Censuses and Surveys, 1980. Classification of Occupations and Coding Index. Her Majesty's Stationery Office, London, UK.

Paustenbach, D.J., Finley, B.L., Long, T.F., 1997. The cricital role of house dust in understanding the hazards posed by constaminated soils. Int. J. Toxicol. 16, 339-362.

Que Hee, S.S., Peace, B., Clark, C.S., Boyle, J.R., Bornschein, R.L., Hammond, P.B., 1985. Evolution of efficient methods to sample lead sources, such as house dust and hand dust, in the homes of children. Environ. Res. 38, 77-95.

Roberts, J.W., Budd, W.T., Ruby, M.G., Bond, A.E., Lewis, R.G., Wiener, R.W., Camann, D.E., 1991. Development and field testing of a high volume sampler for pesticides and toxics in dust. J. Expo. Anal. Environ. Epidemiol. 1, 143-155.

Römkens, P.F.A.M., Schuur, G.W., Lijzen, J.P.A., Rietra, R.P.J.J., Dirven-van Breemen, E.M., 2005. Risico's van cadmium en lood in moestuinen in de Kempen. Alterra Report 1129, Ref Type: Serial Book, Monograph, Wageningen, The Netherlands, Alterra.

Sanchez-Nazario, E.E., Mansilla-Rivera, I., Derieux-Cortes, J.C., Perez, C.M., Rodriguez-Sierra, C.J., 2003. The association of lead-contaminated house dust and blood lead levels of children living on a former landfill in Puerto Rico. P R Health Sci. J. 22, 153-159.

Seifert, B., Becker, K., Hoffmann, K., Krause, C., Schulz, C., 2000. The German Environmental Survey 1990/1992 (GerES II): a representative population study. J. Expo. Anal. Environ. Epidemiol. 10, 103-114.

Staessen, J.A., Amery, A., Lauwerys, R.R., 1992a. Impairment of renal function with increasing blood lead concentrations. N. Engl. J. Med. 327, 1394-1395.
Staessen, J.A., Lauwerys, R.R., Buchet, J.P., Bulpitt, C.J., Rondia, D., Vanrenterghem, Y., Amery, A., The Cadmibel Study Group, 1992b. Impairment of renal function with increasing blood lead concentrations in the general population. N. Engl. J. Med. 327, 151-156.

Staessen, J.A., Lauwerys, R.R., Ide, G., Roels, H.A., Vyncke, G., Amery, A., 1994. Renal function and historical environmental cadmium pollution from zinc smelters. Lancet 343, 1523-1527.

Staessen, J., Roels, H., Vangronsveld, J., Clijsters, H., De Schrijver, K., De Temmerman, L., Dondeyne, F., Van Hulle, S., Wildemeersch, D., Wilms, L., 1995. Preventiemaatregelen voor bodemverontreiniging met cadmium. Tijdschr voor Geneeskd 51, 1387-1395.

Staessen, J.A., Buchet, J.P., Lauwerys, R.R., Lijnen, P., Roels, H., Fagard, R., on behalf of the Working Groups, 1996a. Public health implications of environmental exposure to cadmium and lead: an overview of epidemiological studies in Belgium. J. Cardiovasc. Risk 3, $26-41$.

Staessen, J.A., Roels, H., Fagard, R., for the PheeCad Investigators, 1996b. Lead exposure and conventional and ambulatory blood pressure. A prospective population study. JAMA 275, 1563-1570.

Staessen, J.A., Roels, H.A., Emelianov, D., Kuznetsova, T., Thijs, L., Vangronsveld, J., Fagard, R., for the Public Health and Environmental Exposure to Cadmium (PheeCad) Study Group, 1999. Environmental exposure to cadmium, forearm bone density, and risk of fractures: prospective population study. Lancet 353, $1140-1144$.

Staessen, J.A., Kuznetsova, T., Roels, H.A., Emelianov, D., Fagard, R., for the Public Health and Environmental Exposure to Cadmium Study Group, 2000. Exposure to cadmium and conventional and ambulatory blood pressures in a prospective population study. Am. J. Hypertens. $13,146-156$.

United States Environmental Protection Agency, 1995. Residential sampling for lead: protocols for dust and soil sampling. Final Report, March 1995, (LEAD) [EPA/747/R-95-001], Ref Type: Serial (Book, Monograph), US Environmental Protection Agency, Research Triangle Park, North Carolina.

United States Environmental Protection Agency, 1996. Urban Soil Lead Abatement Demonstration Project, Volume I: EPA Integrated Report, April 1996. [EPA/600/P-93/001aF], Ref Type: Serial (Book, Monograph), US Environmental Protection Agency, Research Triangle Park, North Carolina.

Vangronsveld, J., Carleer, R., Clijsters, H., 1994. Transfer of metals and metalloids from soil to man through vegetables cultivated in polluted gardens: risk assessment and methods for immobilization of these elements in soils. In: Varnavas, S.P. (Ed.), Environmental Contamination. CEP Consultants, Edinburgh, UK, pp. 142-145.

Verougstraete, V., Lison, D., Hotz, P., 2003. Cadmium, lung and prostate cancer: a systematic review of recent epidemiological data. J. Toxicol. Environ. Health 6, 227-255.

Waalkes, M.P., 2003. Cadmium carcinogenesis. Mutat. Res. 533, 107-120. 